\title{
Clinical-radiological dissociation in a patient with nitrous oxide-induced subacute combined degeneration: a case report
}

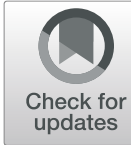

Jiwei Jiang and Xiuli Shang*

\begin{abstract}
Background: Several recent studies have reported subacute combined degeneration (SCD) induced by nitrous oxide $\left(\mathrm{N}_{2} \mathrm{O}\right)$ abuse. However, the association between the evolution of dynamic neuroimaging and clinical manifestations has not been reported in patients with $\mathrm{N}_{2} \mathrm{O}$-induced SCD.

Case presentation: We described the case of a 24-year-old man who developed SCD with inverted V-sign hyperintensities over the posterior aspect of the spinal cord caused by frequent, excessive $\mathrm{N}_{2} \mathrm{O}$ inhalation. One month after treatment, his weakness and paresthesia resolved and serum vitamin $\mathrm{B}_{12}$ levels exceeded the normal levels. However, the hyperintensities had extended horizontally and longitudinally on T2-weighted magnetic resonance imaging (MRl), compared to those on the initial scan. Two months after treatment, the patient experienced some residual numbness in the distal limbs, and his serum homocysteine levels were normal, but the abnormal signals seen on cervical T2-weighted MRI had decreased only slightly compared to those seen on the one-month follow-up MRI. The evolution of conventional MRI findings lagged compared to the clinical manifestation, which was suggestive of a clinical-radiological dissociation.
\end{abstract}

Conclusions: Clinical-radiological dissociation might have occurred in this case because T2-weighted imaging was not sensitive enough to reveal cytotoxic edema. Moreover, the serum vitamin $B_{12}$ level is not a good indicator of cellular vitamin $\mathrm{B}_{12}$. Thus, clinicians should recognize this phenomenon, comprehensively assess the condition of patients with $\mathrm{N}_{2} \mathrm{O}$-induced SCD, and avoid terminating treatment based on the resolution of clinical symptoms and serological results.

Keywords: Subacute combined degeneration, Nitrous oxide, Vitamin $B_{12}$ deficiency, Homocysteine, Magnetic resonance imaging

\section{Background}

Subacute combined degeneration (SCD) is a neurological complication of vitamin $B_{12}$ deficiency, which is typically observed in elderly individuals with malabsorption syndromes and inadequate intake or bioavailability of vitamin $B_{12}$. [1]. Recently, several sporadic cases of otherwise healthy young adults with SCD induced by nitrous oxide $\left(\mathrm{N}_{2} \mathrm{O}\right)$ abuse have been described [2]. However, to the best

\footnotetext{
*Correspondence: wdns1012@163.com

Department of Neurology, the First Affiliated Hospital of China Medical University, Number 155, Nanjing Street, Heping District, Shenyang City 110001, Liaoning Province, China
}

of our knowledge, none of these studies have reported a relationship between the evolution of dynamic neuroimaging and clinical manifestations in a patient with $\mathrm{N}_{2} \mathrm{O}$-induced SCD. Treatment is frequently discontinued by individuals who abuse $\mathrm{N}_{2} \mathrm{O}$ following improvement in the neurological symptoms [3]. Moreover, guidelines for treatment duration have not been established for patients with $\mathrm{SCD}$. Therefore, we reported the case of a young man diagnosed with SCD caused by extensive $\mathrm{N}_{2} \mathrm{O}$ inhalation that led to clinical-radiological dissociation. Furthermore, we highlighted the fact that the condition of patients with $\mathrm{N}_{2} \mathrm{O}$-induced SCD cannot be determined by imaging

C The Author(s). 2020 Open Access This article is licensed under a Creative Commons Attribution 4.0 International License, which permits use, sharing, adaptation, distribution and reproduction in any medium or format, as long as you give appropriate credit to the original author(s) and the source, provide a link to the Creative Commons licence, and indicate if changes were made. The images or other third party material in this article are included in the article's Creative Commons licence, unless indicated otherwise in a credit line to the material. If material is not included in the article's Creative Commons licence and your intended use is not permitted by statutory regulation or exceeds the permitted use, you will need to obtain permission directly from the copyright holder. To view a copy of this licence, visit http://creativecommons.org/licenses/by/4.0/ The Creative Commons Public Domain Dedication waiver (http://creativecommons.org/publicdomain/zero/1.0/) applies to the data made available in this article, unless otherwise stated in a credit line to the data. 
abnormalities, clinical manifestations, or serum vitamin $\mathrm{B}_{12}$ levels alone.

\section{Case presentation}

A 24-year-old man in a wheel-chair presented with numbness in all extremities and worsening lower-extremity weakness for approximately 20 days. He had inhaled $\mathrm{N}_{2} \mathrm{O}$ through an average of approximately 100-200 "whippit" cartridges per day for at least 3 months for recreational purposes. The patient had good dietary intake without alcohol use and did not have a history of smoking or illicit drug use. Neurological examination revealed clear consciousness with fluent speech. No abnormalities were detected in the cranial nerves. However, mild weakness in the upper limbs (grade 4), severe weakness in the lower limbs (grade 3), marked increase in the deep tendon reflexes, impaired joint position and vibration sensation, sensory ataxia, positive bilateral Babinski sign, and positive
Romberg and Lhermitte's signs were observed on neurological examination. Laboratory tests revealed decreased levels of serum red blood cell (RBC) $\left(3.32 \times 10^{12} / \mathrm{L}\right.$, reference range: $\left.4.30-5.80 \times 10^{12} / \mathrm{L}\right)$, hemoglobin $(\mathrm{Hb})(118.4$ $\mathrm{g} / \mathrm{L}$, reference range: $130-175 \mathrm{~g} / \mathrm{L})$, vitamin $B_{12}(98.2$ $\mathrm{pmol} / \mathrm{L}$, reference range: $145-637 \mathrm{pmol} / \mathrm{L})$, and folic acid $(8.38 \mathrm{nmol} / \mathrm{L}$, reference range: $8.83-60.80 \mathrm{nmol} / \mathrm{L})$. Serum homocysteine (Hcy) was considerably elevated (> $50 \mu \mathrm{mol} / \mathrm{L}$, reference range: $5.46-16.20 \mu \mathrm{mol} / \mathrm{L}$ ), which was indicative of functional vitamin $\mathrm{B}_{12}$ deficiency at the cellular level. Cerebrospinal fluid (CSF) assessment yielded normal results. The inflammatory, infectious, and immune biomarkers in CSF and serum were unremarkable. Sagittal spinal cord magnetic resonance imaging (MRI) revealed hyperintensities involving the posterior columns from $\mathrm{C} 2$ to C6 on T2-weighted images (Fig. 1a), with an inverted V-sign on axial MRI (Fig. 1b). Brain and thoracic MRI findings were normal.

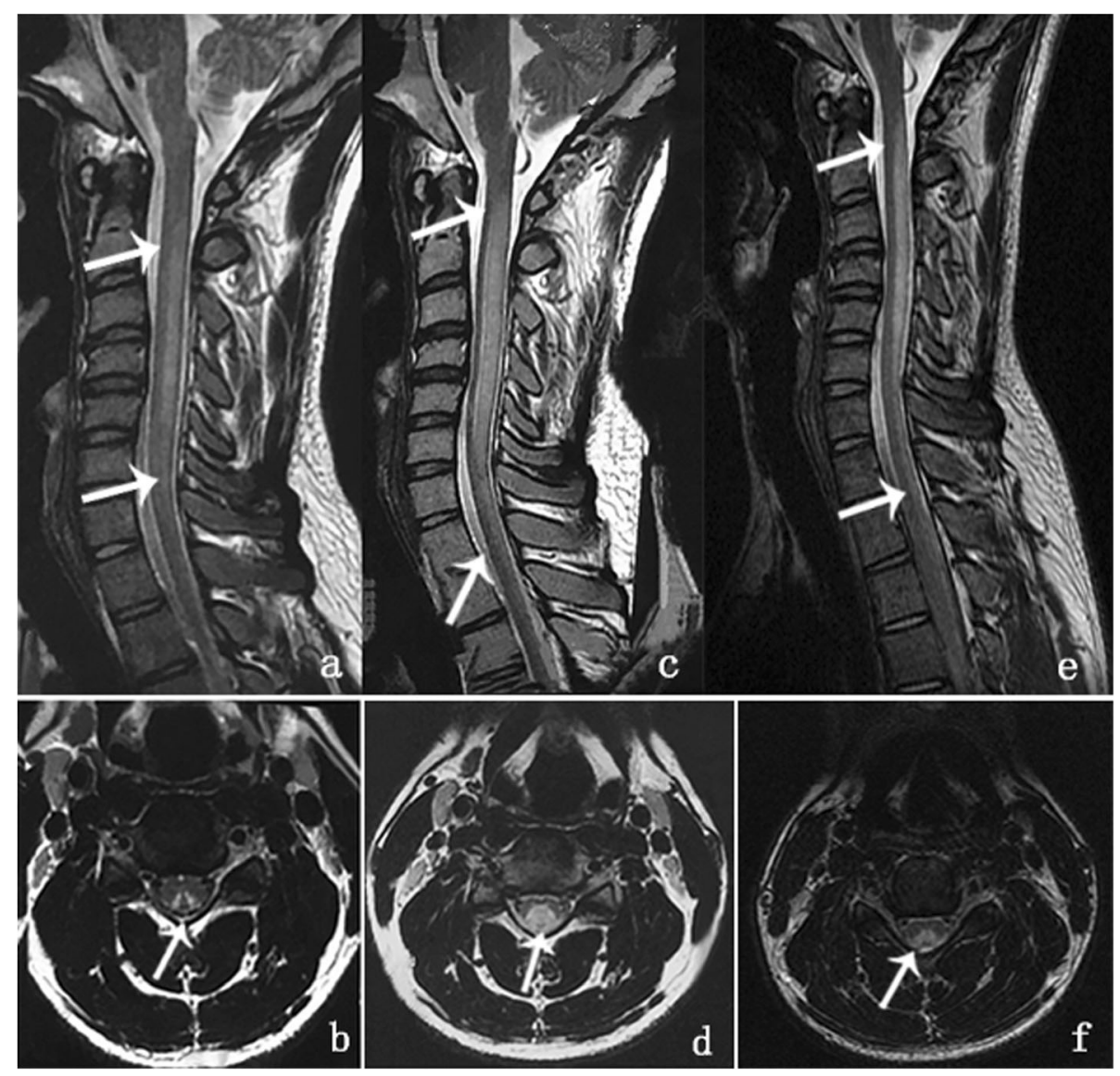

Fig. 1 Magnetic resonance imaging of the cervical spinal cord. a. Sagittal T2-weighted imaging showed increased intramedullary signal intensity along the posterior column of the spinal cord extending from C2 to C6 on August 3, 2018. b. A V-shaped hyperintensity on axial T2-weighted imaging at the C4 level was seen within the dorsal cervical spinal cord on August 3, 2018. c. Sagittal T2-weighted imaging showed abnormal, longitudinally and horizontally extensive hyperintensities involving the lateral and posterior columns of the spinal cord extending from C1 through T2 on September 3, 2018. d. Axial T2-weighted imaging at the C4 level showed a ball-shaped hyperintensity on September 3, 2018. e. Sagittal T2-weighted imaging showed hyperintensity along the posterior column of the spinal cord extending from C1 to T1 on October 4, 2018. f. Axial T2-weighted imaging at the C4 level showed that the V-shaped hyperintensity had decreased compared to that in September (d) 
The patient was diagnosed with SCD of the spinal cord induced by $\mathrm{N}_{2} \mathrm{O}$ abuse. Treatment with a high dose of supplementary intramuscular vitamin $\mathrm{B}_{12}$ injections (1.5 mg per day), oral folic acid ( $15 \mathrm{mg}$ per day), and abstinence from $\mathrm{N}_{2} \mathrm{O}$ led to a gradual improvement in the patient's symptoms. One month later, the symptoms of weakness and paresthesia were resolved; the patient could walk unsupported with some residual gait impairment. The serum $\mathrm{RBC}, \mathrm{Hb}$, and folic acid levels improved to normal, and the serum vitamin $B_{12}$ level increased to more than $1476 \mathrm{pmol} / \mathrm{L}$ (the maximum measurable value). However, the patient's serum Hcy remained elevated $(19.02 \mu \mathrm{mol} / \mathrm{L})$. At this time, we observed an interesting phenomenon. The hyperintensities on T2-weighted images had extended, both horizontally and longitudinally, from $\mathrm{C} 1$ to $\mathrm{T} 2$ (Fig. 1c), resembling a "ball" on the axial images, despite the improvement in the patient's clinical symptoms and laboratory values (Fig. 1. d). Importantly, the patient had had no exposure to hormones or $\mathrm{N}_{2} \mathrm{O}$. He was discharged with a prescription for vitamin $B_{12}$ supplements. The patient's gait had improved, and he experienced only mild paresthesia of the distal limbs during the two-month follow-up. Serum Hcy had improved to normal levels. Moreover, the abnormal signals seen on T2-weighted images had decreased compared to those on the one-month followup MRI, but were still more extensive than those seen on the initial MRI (Fig. 1 e, f). It seemed that a clinicalradiological dissociation had occurred, and conventional MRI findings had consistently lagged behind the clinical and laboratory manifestations.

\section{Discussion and conclusions}

Although several cases of SCD associated with vitamin $\mathrm{B}_{12}$ deficiency induced by $\mathrm{N}_{2} \mathrm{O}$ abuse have been described, the relationship between the evolution of dynamic neuroimaging and clinical manifestations has never been reported. To the best of our knowledge, this is the first report of clinical-neuroimaging dissociation in a patient with $\mathrm{N}_{2} \mathrm{O}$-induced SCD.

$\mathrm{N}_{2} \mathrm{O}$ induces $\mathrm{SCD}$ by irreversibly oxidizing the cobalt ion of vitamin $\mathrm{B}_{12}$ (cobalamin). The highly nucleophilic cobalamin (1+) ion, which is a product of the methylation of Hcy (to form methionine), commonly reacts with methyltetrahydrofolate to regenerate methylcobalamin [4]. Once the cobalt ion is oxidized by $\mathrm{N}_{2} \mathrm{O}$, methylcobalamin, as a cofactor of methionine synthase in the transfer of Hcy to methionine, subsequently inhibits S-adenosylmethionine, which is essential for the methylation of myelin sheath phospholipids [5]. Thus, inactivation of vitamin $B_{12}$ metabolism results in the demyelination of the spinal cord [6].

Few patients with cobalamin deficiency have normal serum vitamin $B_{12}$ levels. According to the metabolic pathway described above, a normal serum level of vitamin $B_{12}$ is not indicative of the precise or timely cellular availability of vitamin $B_{12}$. Instead, elevated serum levels of Hcy or methylmalonic acid are better biomarkers for the diagnosis of cellular vitamin $B_{12}$ deficiency [7]. Although the serum levels of vitamin $B_{12}$ and folic acid returned to normal in this patient, elevated Hcy levels showed greater value as an indicator of cellular vitamin $\mathrm{B}_{12}$ deficiency. Thus, demyelination of the cervical spinal cord may still exist in this patient even if the serum vitamin $B_{12}$ and folic acid levels are normal.

Moreover, the lag in the conventional MRI findings compared to clinical manifestations was similar to that seen in central pontine myelinolysis (CPM). In 1996, SCD was classified as a pure myelinolytic disease with no apparent loss of myelin or areas of partial neuropathological remyelination [8]. Hence, we surmise that the clinical-radiological dissociation observed in our case may be related to the neuropathological basis of intramedullary and interstitial edema, similar to that observed in CPM. Hyperintensity on spinal cord diffusionweighted imaging (DWI) and a corresponding hypointensity on the apparent diffusion coefficient maps have been previously reported in patients with $\operatorname{SCD}[9,10]$. These acute demyelinating lesions manifest as restricted diffusion, indicating an energy failure, which results in cytotoxic edema.

DWI provides quantitative and qualitative functional information on the microdiffusion of water molecules at the cellular level and has been widely used for the evaluation of a variety of brain disorders, such as acute cerebral infarction [11]. Similarly, DWI is superior to T2weighted imaging for the diagnosis of cytotoxic edema in the early stages. Hence, we hypothesize that T2weighted imaging is not sensitive enough to reflect the early intramedullary and interstitial cytotoxic edema caused by SCD, which may be another possible reason for the clinical-imaging dissociation in the present case.

In conclusion, we recommend that $\mathrm{N}_{2} \mathrm{O}$ abuse should be considered in patients presenting with $\mathrm{SCD}$, especially if the patient is young and otherwise healthy. The inability of serum vitamin $B_{12}$ to reflect cellular vitamin $\mathrm{B}_{12}$ levels and that of T2-weighted imaging in revealing cytotoxic edema in the early stages may have contributed to the clinical-imaging dissociation. Thus, clinicians should comprehensively assess the condition of patients with $\mathrm{N}_{2} \mathrm{O}$-induced $\mathrm{SCD}$, avoid terminating treatment due to the resolution of clinical symptoms and serological findings, and carefully evaluate worsening imaging results for possible clinical-imaging dissociation.

\section{Abbreviations}

CPM: central pontine myelinolysis; CSF: cerebrospinal fluid; DWI: diffusionweighted imaging; Hb: hemoglobin; Hcy: homocysteine; MRI: magnetic resonance imaging; $\mathrm{N}_{2} \mathrm{O}$ : nitrous oxide; $\mathrm{RBC}$ : red blood cells; $\mathrm{SCD}$ : subacute combined degeneration 


\section{Acknowledgments}

The authors would like to thank the patient and his family for their participation and help.

We would like to thank Editage (www.editage.cn) for English language editing.

\section{Authors' contributions}

J): conceptualization and design of the study, interpretation of data, drafting and revising the manuscript. XS: critical revision of the manuscript for important intellectual content, study supervision. All authors have read and approved the manuscript.

\section{Funding}

This study was supported by the National Natural Science Foundation of China (81871104). The funding body supplied this manuscript with funding for data collection, analysis, and interpretation, as well as writing the manuscript.

\section{Availability of data and materials}

Data has not been made accessible in the interest of protecting the patient's privacy.

\section{Ethics approval and consent to participate}

Not applicable.

\section{Consent for publication}

Written informed consent for publication was obtained from the patient. A copy of the written consent is available for review by the editor upon request.

\section{Competing interests}

The authors declare that they have no competing interests.

Received: 20 January 2019 Accepted: 12 March 2020

Published online: 17 March 2020

\section{References}

1. Green R, Allen LH, Bjørke-Monsen AL, Brito A, Guéant JL, Miller JW, et al. Vitamin B12 deficiency. Nat Rev Dis Primers. 2017;3:17040.

2. Patel KK, Mejia Munne JC, Gunness VRN, Hersey D, Alshafai N, Sciubba D, et al. Subacute combined degeneration of the spinal cord following nitrous oxide anesthesia: a systematic review of cases. Clin Neurol Neurosurg. 2018; 173:163-8.

3. Cao J, Su ZY, Xu SB, Liu CC. Subacute combined degeneration: a retrospective study of 68 cases with short-term follow-up. Eur Neurol. 2018; 79:247-55.

4. Jordan JT, Weiser J, Van Ness PC. Unrecognized cobalamin deficiency, nitrous oxide, and reversible subacute combined degeneration. Neurol Clin Pract. 2014;4:358-61

5. Hathout $L, E l-S a d e n ~ S$. Nitrous oxide-induced $B_{12}$ deficiency myelopathy: perspectives on the clinical biochemistry of vitamin $B_{12}$.J Neurol Sci. 2011; 301:1-8.

6. Hunt A, Harrington D, Robinson S. Vitamin B12 deficiency. BMJ. 2014;349: g5226.

7. Briani C, Dalla Torre C, Citton V, Manara R, Pompanin S, Binotto G, et al. Cobalamin deficiency: clinical picture and radiological findings. Nutrients. 2013:5:4521-39.

8. Powers J. Pathology of myelin. Mol Chem Neuropathol. 1996;27:31-8.

9. Tian C. Hyperintense signal on spinal cord diffusion-weighted imaging in a patient with subacute combined degeneration. Neurol India. 2011;59:429-31.

10. Kim EY, Lee SY, Cha SH, Yi KS, Cho BS, Kang MH. Subacute combined degeneration revealed by diffusion-weighted imaging: a case study. Clin Neuroradiol. 2013:23:157-9.

11. Simonsen CZ, Madsen MH, Schmitz ML, Mikkelsen IK, Fisher M, Andersen G. Sensitivity of diffusion- and perfusion-weighted imaging for diagnosing acute ischemic stroke is 97.5\%. Stroke. 2015:46:98-101.

\section{Publisher's Note}

Springer Nature remains neutral with regard to jurisdictional claims in published maps and institutional affiliations.

Ready to submit your research? Choose BMC and benefit from:

- fast, convenient online submission

- thorough peer review by experienced researchers in your field

- rapid publication on acceptance

- support for research data, including large and complex data types

- gold Open Access which fosters wider collaboration and increased citations

- maximum visibility for your research: over $100 \mathrm{M}$ website views per year

At $\mathrm{BMC}$, research is always in progress.

Learn more biomedcentral.com/submissions 